\title{
Overexpression of a truncated form of the MSN2 gene enhances the initial rate of ethanol production in an industrial fuel-ethanol Saccharomyces cerevisiae strain
}

\author{
Augusto Bücker ${ }^{1}$, Davi Ludvig Gonçalves*, Júlio Cézar Espírito Santo², Boris Stambuk \\ From 5th Congress of the Brazilian Biotechnology Society (SBBIOTEC) \\ Florianópolis, Brazil. 10-14 November 2013
}

\section{Background}

The yeast strain CAT-1 isolated from a Brazilian fuelethanol plant (Babrzadeh et al. 2009) is one of the most common strain used nowadays due to its very efficient fermentation capacity, especially at high sugar concentrations and under the stressful industrial conditions. Since the transcription factor genes MSN4, MSN2, YAP1 and HSF1 of tolerant yeast strains are highly expressed under ethanol stress [1], we generated a CAT-1 derived strain named ATT- 6 that overexpresses a truncated form of the transcription activator Msn2 through genomic engineering and analyzed the ethanol stress tolerance and fermentation capacity of this modified strain.

\section{Methods}

Following the procedure described by Petracek and Longtine [2], for the construction of a yeast strains overexpressing a truncated form of the MSN2 gene, a DNA fragment containing the $K a n^{\mathrm{r}}$ which confers resistance to G418 (geneticin), flanked by LoxP regions and the constitutive PADH1 promoter, was integrated into the genomic locus of the MSN2 gene of CAT-1, deleting the $\mathrm{N}$-terminal region (first 48 amino acids) of the protein. The effect of $12-16 \%(\mathrm{v} / \mathrm{v})$ ethanol addition on cell growth of the strain was evaluated in 96-well plates using a Tecan GENios microplate reader at $30^{\circ} \mathrm{C}$ and $110 \mathrm{rpm}$. Fermentation performance was determined using high sucrose concentration $(200 \mathrm{~g} / \mathrm{L})$.

'Department of Biochemistry, Federal University of the Santa Catarina

UFSC, Florianópolis, SC, 88040-970, Brazil

Full list of author information is available at the end of the article

\section{Results and conclusions}

Under microaerobic conditions, the industrial ATT-6 strain overexpressing a truncated MSN2 gene showed increased growth rates and increased tolerance to up to $16 \%(\mathrm{v} / \mathrm{v})$ ethanol stress, while the industrial control CAT1 strain did not show cell growth before 60 hours. These results were consistent with those obtained by Hong et al. [3], indicating that overexpression of a truncated MSN2 can increase ethanol tolerance in a laboratory S. cerevisiae strain. Next, we investigated whether this improvement in cellular viability under high ethanol conditions leads to higher ethanol productivities during ethanol fermentation. We used high sucrose concentration $(200 \mathrm{~g} / \mathrm{L})$ to expose yeast cells to high ethanol concentrations, caused not only by the initially added ethanol (12-16\%), but also by the ethanol produced during fermentation. Our results show that the genetically modified strain ATT-6 grew slightly better than the control strain in the presence of supplemented ethanol. Ethanol production of the ATT- 6 strain also showed slight initial higher ethanol productivity during the first 8 hours, when compared to the parental strain. Furthermore, the ATT-6 strain also presents higher invertase activity needed for the sucrose consumption, a result in accordance with Geng and Laurent [4] that indicates that Msn2/Msn4 act specifically in the early phase of SUC2 induction. Since there is limited information available for the function of the truncated form of MSN2, further studies on its regulatory roles for ethanol tolerance are needed. In conclusion, our results show that the industrial ATT-6 strain that overexpresses the truncated MSN2 allele is more tolerant to ethanol and produced more ethanol than the control unmodified strain. 


\section{Acknowledgements}

This work was supported in part by grants from the Brazilian agencies CAPES, CNPq and FINEP.

\section{Authors' details}

'Department of Biochemistry, Federal University of the Santa Catarina UFSC, Florianópolis, SC, 88040-970, Brazil. "2Instituto Tecnológico Vale - ITV Belém, PA, 66055-090, Brazil.

Published: 1 October 2014

\section{References}

1. Ma M, Liu ZL: Quantitative transcription dynamic analysis reveals candidate genes and key regulators for ethanol tolerance in Saccharomyces cerevisiae. BMC Microbiol 2010, 10:169.

2. Petracek ME, Longtine MS: PCR-Based Engineering of Yeast Genome. Methods Enzymol 2002, 35:445-469.

3. Hong M, Lee K, Yu BJ, Sung Y, Park SM, Koo HM, et al: Identification of gene targets eliciting improved alcohol tolerance in saccharomyces cerevisiae through inverse metabolic engineering. J Biotechnol 2010, 149:52-9.

4. Geng F, Laurent BC: Roles of SWI/SNF and HATs throughout the dynamic transcription of a yeast glucose-repressible gene. EMBO J 2004, 23:127-37.

5. Babrzadeh F, Jalili R, Wang C, Shokralla S, Pierce S, Robinson-Mosher A, Nyren P, Shafer RW, Basso LC, Amorim HV, Oliveira AJ, Davis RW,

Ronaghi M, Gharizadeh B, Stambuk BU: Whole-genome sequencing of the efficient industrial fuel-ethanol fermentative Saccharomyces cerevisiae strain CAT-1. Mol Genet Genomics 2012, 287:485-494.

doi:10.1186/1753-6561-8-S4-P126

Cite this article as: Bücker et al:: Overexpression of a truncated form of the MSN2 gene enhances the initial rate of ethanol production in an industrial fuel-ethanol Saccharomyces cerevisiae strain. BMC Proceedings 2014 8(Suppl 4):P126.

\section{Submit your next manuscript to BioMed Central and take full advantage of:}

- Convenient online submission

- Thorough peer review

- No space constraints or color figure charges

- Immediate publication on acceptance

- Inclusion in PubMed, CAS, Scopus and Google Scholar

- Research which is freely available for redistribution

Submit your manuscript at www.biomedcentral.com/submit 